\title{
Sensitivity of pines in Mexico to temperature varies with age
}

\author{
MARÍN POMPA-GARCÍA \\ Facultad de Ciencias Forestales, Universidad Juárez del Estado de Durango, Av. Papaloapan y \\ Blvd. Durango, Durango 34120, México \\ Cooresponding author; email: mpgarcia@ujed.mx
}

\begin{abstract}
MARTÍN A. HADAD
Centro de Investigaciones de la Geosfera y Biosfera-CONICET, Universidad Nacional de San Juan, Rivadavia, San Juan, Argentina; Departamento de Dendrocronología e Historia Ambiental, Instituto Argentino de Nivología, Glaciología y Ciencias Ambientales-CONICET, Mendoza, Argentina
\end{abstract}

Received: January 21, 2016; accepted: May 27, 2016

\begin{abstract}
RESUMEN
México tiene abundancia de especies de Pinus, con P. cooperi como especie dominante de gran importancia ecológica. En este estudio se comparó la sensibilidad climática de dos clases de edad de árboles de P. cooperi que crecen en la Sierra Madre Occidental: jóvenes ( $<80$ años) y maduros ( $\geq 80$ años). Se desarrolló una curva regional de estandarización del crecimiento del ancho de anillo para las dos clases de edad. El análisis estadístico mostró que el crecimiento anual del ancho de anillo del árbol fue similar entre las dos clases. Sin embargo, se encontró que el efecto de temperaturas elevadas durante el invierno previo son dependientes de la edad; esto es, temperaturas máximas y mínimas tienen efectos opuestos en el crecimiento subsecuente del árbol. Inviernos cálidos tienen efectos negativos en el crecimiento radial, y éstos son más fuertes en árboles jóvenes que en maduros; mientras que las temperaturas mínimas promueven el crecimiento. Sin embargo, no hubo diferencia en crecimiento radial entre las dos clases de edad con base en la precipitación. En escenarios de cambio climático, un incremento de la temperatura podría afectar más a los árboles jóvenes que a los maduros. Estos efectos de temperatura elevada pueden llevar a la reducción del crecimiento y la muerte subsecuente de los árboles. Estos resultados podrían ayudar a los manejadores de bosques a desarrollar criterios relacionados con la gestión forestal para esta especie.
\end{abstract}

\section{ABSTRACT}

Mexico has an abundance of Pinus species with P. cooperi as a dominant tree species of great ecological importance. In this study, we compared the climate sensitivity of $P$. cooperi trees of two age classes growing in the Sierra Madre Occidental: younger ( $<80$ years) and older ( $\geq 80$ years) trees. A regional curve standardization (RCS) of growth ring width was developed for these two age classes. Our statistical analysis showed that annual tree growth was similar between the two age classes in absolute values of tree-ring widths. However, we found that the effects of rising temperatures during the previous winter are age-dependent; that is, maximum and minimum temperatures have opposite effects on the subsequent tree growth. Warming winter maximum temperatures have negative effects on radial growth, which are stronger in younger trees, whilst minimum winter temperatures enhance the growth. However, no difference in radial growth was observed between the two age classes based on precipitation. In climate change scenarios, an increase in temperature would affect younger trees of $P$. cooperi more than older trees. These effects of increased temperature may lead to a decrease in the growth and subsequent death of the trees. These results could help land managers to develop criteria related to forest management regarding P. cooperi.

Keywords: Age classes, climate change, Sierra Madre Occidental, tree ring. 


\section{Introduction}

The structure of most of the world's forests is changing. New forest management schemes have resulted in changes in stand age and forest structure (Didion et al., 2007). In Mexico, the major approaches for managing its temperate forests are based on selective logging, with a minimum cutting diameter $(30 \mathrm{~cm}$ in the case of pines) (Gadow et al., 2004). Therefore, the use of selective logging as a forest management method tends to reduce old-growth forests. In addition, future climate change is predicted to have major effects on the ecology and distribution of species (Williams et al., 2013). An extensive literature supports the hypothesis that climate change plays an important role in determining the development of structure and function of forest ecosystems (Schuster and Oberhuber, 2013). Because future forest structure and composition will be mainly a consequence of current management practices, understanding environmental factors that control natural regeneration is important to predict dynamics in mixed Mexican forests.

The physiological processes of growth change as trees age (Hinckley et al., 2011), since some physiological processes, such as photosynthetic capacity and the consequent radial growth, change with age. Körner (2006) suggests that the rate of change in radial growth diminish with age in response to changing resource availability. One of the physiological processes that may partially explain how age can control the sensitivity of trees to climate is hydraulic limitation (Carrer and Urbinati, 2004; Yu et al., 2008; Hadad et al., 2015). This restriction may contribute to the limitation of tree growth as the size of the tree increases (Ryan et al., 1997). Therefore, hydraulic limitation, as a physiological process, could cause trees of different age classes to exhibit different levels of climate sensitivity.

Dendrochronology provides a useful tool for understanding the relationship between climate and trees (Fritts, 1976), as shown by several research studies as well as other projects currently underway worldwide (Hughes et al., 2011). Many of these studies have documented how climate influences the distribution of forests. For instance, Pompa-García and Némiga (2015) showed that El Niño is likely to enhance growth of forests via positive effects related to soil moisture in the preceding winter. However, not all processes are simply related to ENSO. For example, Cook and Seager (2013) argue that shifts in the seasonal distribution of precipitation within the North American Monsoon (NAM) over northwestern Mexico may have major ecological consequences, reinforcing the need to understand how changes in precipitation affect tree growth.

Additionally, several recent studies based on tree rings have demonstrated that the response to climate varies with stand age (e.g., Esper et al., 2008; Yu et al., 2008; Rozas et al., 2009; Vieira et al., 2009; Wang et al., 2009; Copenheaver et al., 2011; Hadad et al., 2015). However, Colenutt and Luckman (1991) have suggested that in some cases this duality has not been proven; for example, they found no difference in the response of both young and older Larix lyallii trees to climate.

With these precedents, analyzing the response of trees to climate can show how forest and stand age structure may result in an increase of forest vulnerability under different climate change scenarios. Therefore, although the above research recognizes that variations exist in the sensitivity of growth rings to climate based on stand age, knowledge in the field of plant ecology is still limited and should be explored in more detail (Hinckley et al., 2011).

Mexico has more native pine species than any other country worldwide (Farjon, 2010), and the ecological and economic importance of these species has received global recognition (Silva et al., 2014). The forests of the Sierra Madre Occidental are characterized by an abundance of Pinus spp., with $P$. cooperi as the dominant species having great ecological importance (Cruz-Cobos et al., 2008). Further, the potential dendrochronological amplitude of this species provides a good opportunity to evaluate how climatic drivers constrain tree growth (Pompa-García et al., 2015).

However, at the moment the effects of climate on this representative species based on stand age in Mexican ecosystems remain unknown. The effects of climate based on stand age have implications related to forest productivity (Bond, 2000), carbon cycles (Viveros-Viveros et al., 2009) and mechanisms of adaptation to climate change (Bošel'a et al., 2014). For example, in the study area, the removal of mature trees of $P$. cooperi forests (i.e., selective logging) results in generally younger stand ages. If younger forests of this species are more susceptible to climate change than older forests, this may have strong implications related to forest management. 
Therefore, the aim of this study was to compare the climatic sensitivity of differently aged $P$. cooperi trees from the Sierra Madre Occidental.

\section{Methods}

\subsection{Study area and data}

The study area corresponds to a sector of the Sierra Madre Occidental where $P$. cooperi occurs, located between $23^{\circ} 44^{\prime}-24^{\circ} 13^{\prime} \mathrm{N}$, and $105^{\circ} 22^{\prime}-05^{\circ} 34^{\prime} \mathrm{W}$. The region's temperate climate experiences long cool summers with generally sub-humid conditions caused by the monsoon influence (Seager et al., 2009). The rainy season starts with the onset of the NAM in late June or early July. A second precipitation falls during the cold season (November-February) in the form of westerly frontal systems that originate from the Pacific Ocean (Higgins and Shi, 2001). Maximum monthly temperatures values are observed from May to June. The hydroclimatic variability over Mexico is controlled by sea surface temperatures (SST) of the tropical Pacific and Atlantic oceans (Seager et al., 2009). Warm SSTs in the equatorial Pacific and El Niño events characterize wet winters, whilst cold SSTs and La Niña events correspond to dry winters. In northern Mexico, El Niño events are related to moist-cool conditions that enhance forest productivity and tree growth (Stahle and Cleaveland, 1993). In fact, previous winter conditions have been identified as major drivers for radial tree growth in $P$. cooperi (Stahle and Cleaveland, 1993; Pompa-García and Némiga, 2015).

We selected five sites at which increment cores were collected from a height of $1.3 \mathrm{~m}$. Tree ring samples were collected from eight to 13 trees per site (Table I).

In the laboratory, to highlight the anatomical structure of the growth rings, samples were dried, mounted, placed on wooden supports and sanded with sandpaper with progressive grit sizes from 60 to 1200 (Stokes and Smiley, 1968). The ring width was measured using the Velmex measuring system (Velmex, Inc., Bloomfield, NY, USA), which is accurate to $0.001 \mathrm{~mm}$. The quality of measurements of the series of ring widths was controlled statistically using the COFECHA software (Holmes, 1983). At least $80 \%$ of the increment cores reached the pith.

\subsection{Developing timelines}

The samples were separated into two age classes, younger ( $<80$ years) and older ( $\geq 80$ years). A regional curve standardization (RCS) of growth ring width was built for each age class. This method aligns the measurements of ring width of all trees by biological age; then, the arithmetic mean of the ring width for each biological age is calculated. This technique creates different RCS values for each biological age analyzed. In one application of the RCS, each ring size is divided by the value of the RCS curve for the age of the respective ring to create an index for each tree. This allows the creation of indices for the various chronologies with the arithmetic mean of the indices of each tree and for each calendar year (Briffa and Melvin, 2011). The indices of growth ring width (TRI) of each age class were calculated using Arstan 4.0c software (Cook, 1985). We compared the residual chronology with the climatic variables.

The intensity of the common signal in each chronology was estimated by a running series of average correlations (Rbar) (Wigley et al., 1984). This shows the mean correlation between the series, which corresponds to a common expression according to the percentage of variance in all the series analyzed. The Rbar value may change in certain sectors of the time series as a result of changes in signal strength,

Table I. Descriptive data of Pinus cooperi sampled plots.

\begin{tabular}{lccccc}
\hline \multirow{2}{*}{ Site } & \multicolumn{2}{c}{ Geographic coordinates } & Elevation & Trees $(\mathrm{n})$ & $\begin{array}{c}\text { Mean DBH } \\
(\mathrm{cm})\end{array}$ \\
\cline { 2 - 3 } & Longitude $\left({ }^{\circ} \mathrm{W}\right)$ & Latitude $\left({ }^{\circ} \mathrm{N}\right)$ & $($ masl $)$ & & 47.2 \\
\hline 1 & 105.534944 & 23.747306 & 2905 & 10 & 50.1 \\
2 & 105.533583 & 23.752605 & 2813 & 10 & 43.6 \\
3 & 105.503194 & 23.742139 & 2680 & 8 & 40.2 \\
4 & 105.379611 & 24.189083 & 2424 & 10 & 52.3 \\
5 & 105.464778 & 24.177583 & 2375 & 13 & \\
\hline
\end{tabular}

DBH: diameter at breast height. 
which may be caused by differences in sample size. The expressed population signal (EPS) is also considered; EPS measures the degree of goodness of a particular chronology compared with population chronology based on an infinite number of trees (Wigley et al., 1984). The EPS depends largely on the number of trees used in the construction of the chronology. The acceptance threshold of EPS is 0.85 (Wigley et al., 1984). To examine the temporal properties of the chronology, both Rbar and EPS were developed based on a 50-year sliding window with a 25-year overlap. The following statistics of the individual series of ring width for each age group were obtained: average value of the ring $(M)$, ring medium sensitivity $(M S)$, and ring standard deviation (SD) (Fritts, 1976).

\subsection{Meteorological data and statistical analysis}

Climate variables were monthly total precipitation $(P)$ in mm, maximum monthly temperature $\left(T_{\max }\right)$, mean monthly temperature $\left(T_{\text {mean }}\right)$ and minimum monthly temperature $\left(T_{\min }\right)$ in ${ }^{\circ} \mathrm{C}$ for the period 1946-2010 obtained from the El Salto and Otinapa meteorological stations (CNA, 2012). The time lapse analyzed corresponds to a period of 15 months sterting from July on the previous year of growth to September, corresponding to the end of the current growing season.

Individual series will be analyzed through the Kruskal-Wallis nonparametric test $(p<0.05)$ to study the growth in different age classes of $P$. cooperi. The Kruskal-Wallis test does not assume normal distribution (see Hollander and Wolfe, 1973), since age classes have different mean and standard deviations.

The influence of climate on growth ring chronologies for different age classes of $P$. cooperi was assessed by the Pearson's correlation coefficient analysis (Blasing et al., 1984). We investigated the correlation coefficient with DENDROCLIM2002 software (Biondi and Waikul, 2004), which applies the statistical significance of Pearson's correlation coefficients by calculating a $95 \%$ interval based on 1000 bootstrapped resamples of the data. Correlation coefficients were calculated for each age class using residual chronologies.

To detect those monthly climate variables with direct relations to TRI $(p<0.1)$, we used multiple regressions (i.e., the stepwise method) with the statistical software SAS/STAT® (SAS, 2004). The stepwise method looks at all the variables already included in the model and deletes any variable that does not produce an $F$ statistic significant at the required level (SAS, 2004).

\section{Results}

Table II shows the dendrochronological statistics calculated for the residual chronologies for each age class of $P$. cooperi. The extension of the timeline for the younger class is 1933-2011 and 1817-2011 for the older class (Fig. 1). The mean tree ring width and mean sensitivity for the younger class are $2.92 \mathrm{~mm}$ and 0.262 , respectively; for the older class they are $1.68 \mathrm{~mm}$ and 0.248 , respectively (Table II).

The EPS values greatly exceed the threshold of acceptance (0.85) in both classes (Table II and Fig. 2). The results of the Kruskal-Wallis test for the two age classes were significantly different $(p<0.0001$; $H=2378.4)$.

When comparing the chronologies of the two age classes with $T_{\min }$, younger trees had a positive and significant response $(p<0.05)$ in the months of December, January and February of the current growth period, and only the months of January and February were significant for older trees (Fig. 3a). In the case of $T_{\max }$ younger trees have a negative and significant relationship $(p<0.05)$ in August to the previous growth

Table II. Summary of the dendrochronological statistics calculated for residual chronologies of Pinus cooperi.

\begin{tabular}{lcccccc}
\hline $\begin{array}{c}\text { Chronology } \\
\text { class }\end{array}$ & $\begin{array}{c}\text { Number of } \\
\text { tree/radii }\end{array}$ & $\begin{array}{c}\text { Chronology } \\
\text { span }\end{array}$ & $\begin{array}{c}\text { Mean ring } \\
\text { width }(\mathrm{mm})\end{array}$ & MS & SD & EPS \\
\hline Younger & $26 / 69$ & $1933-2011$ & 2.92 & 0.262 & 0.198 & 0.965 \\
Older & $24 / 80$ & $1817-2011$ & 1.68 & 0.248 & 0.197 & 0.911 \\
\hline
\end{tabular}

EPS: expressed population signal; MS:, mean sensitivity; SD: standard deviation. Age classes are defined as younger $<80$ years) and older ( $\geq 80$ years). 

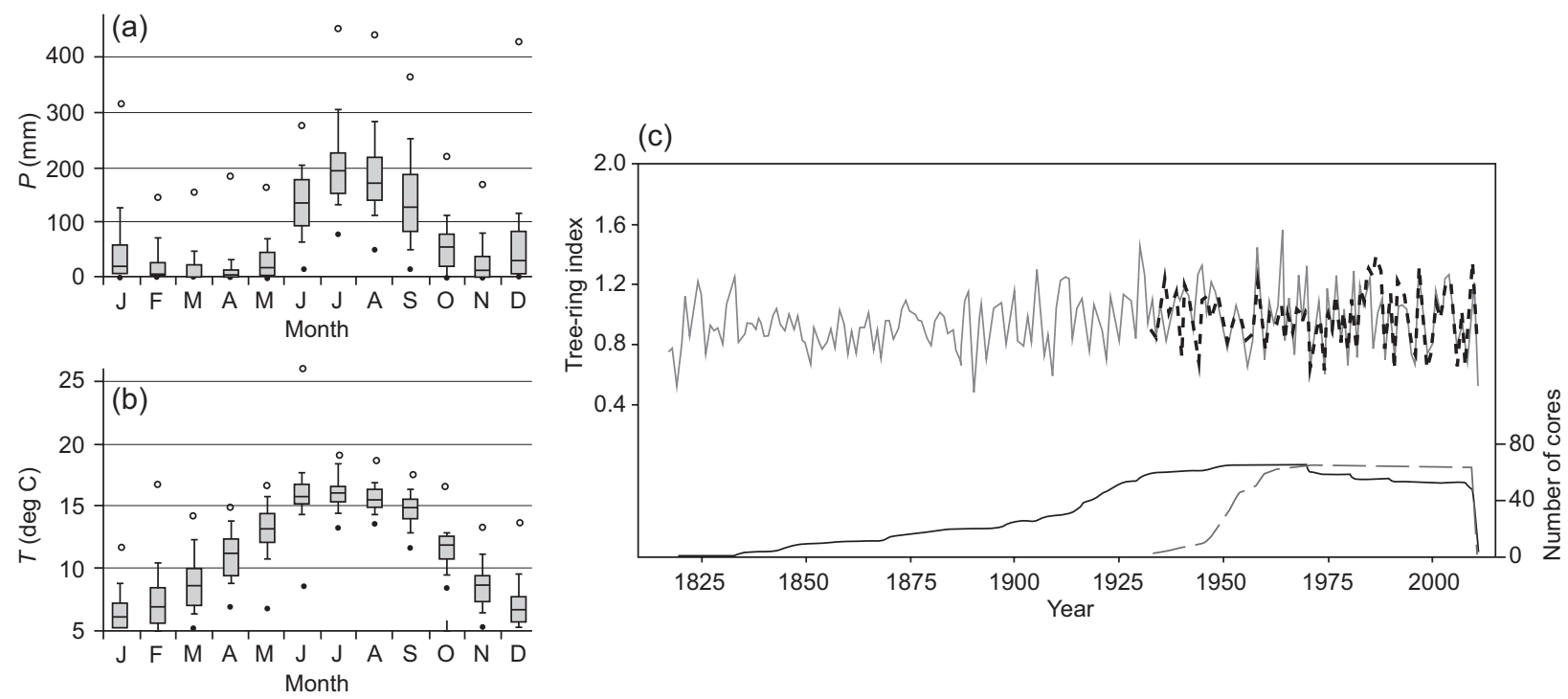

Fig. 1. (a) and (b) climatographs of monthly precipitation distribution $\mathrm{P}(\mathrm{a})$ and temperature $\mathrm{T}$ (b) for the period 19462010. (c) Pinus cooperi residual regional tree-ring index chronologies by age class. Black and dashed lines represent older ( $\geq 80$ years) and younger $(<80$ years) classes, respectively. Sample depth (number of radii) is shown at the bottom (right).



Fig. 2. Running series of average correlations (Rbar; gray line) and expressed population signal (EPS; black line) curves for (a) older $(\geq 80$ years) and (b) younger $(<80$ years) age classes of Pinus cooperi chronologies.

period and in January and February to the current growth period. Meanwhile, older trees showed no significant relationship $(p<0.05)$ (Fig. 3b). When comparing the chronologies with total monthly precipitation, both age classes had a significant and positive response $(p<0.05)$ from November to March, with no observed differences between age classes (Fig. 3c).

We observed significant and positive differences between age classes in the April precipitation for younger trees and significant differences in May and June for older trees. The linear regression indicated that TRI was significantly associated with climatic variables. Table III shows details of the $T_{\max }$ monthly analysis for different age classes. For TRI, most of the variables selected for the models were those from the previous winter. Previous winter $T_{\max }\left(P W T_{\max }\right)$ (i.e., from previous November to the current January) was mainly associated with TRI ( $p<0.1$, e.g. the model has statistically significant predictive capability in the regression) for both age classes. However, the stepwise regression found that $P W T_{\max }$ is more related to the younger class than to the older class. Models applied to older and younger classes sites explained 13 and $50 \%$ of the total variance of TRI, respectively. The $P W T_{\max }$ parameters estimates obtained for younger trees with multivariate models indicated that this variable had a greater association with radial growth in this class.

\section{Discussion}

Past studies of the age-dependent response of forests to climate change have provided contrasting answers. While some authors argue that stand age affects the signals of climate that can be observed in plants (e.g., Szeicz and MacDonald, 1994; Carrer and Urbinati, 2004; Linderholm and Linderholm, 2004; Esper et al., 2008; Rozas et al., 2009; Vieira et al., 2009; Hadad et al., 2015), other studies show that climate growth responses are age independent (e.g., Fritts, 1976; 

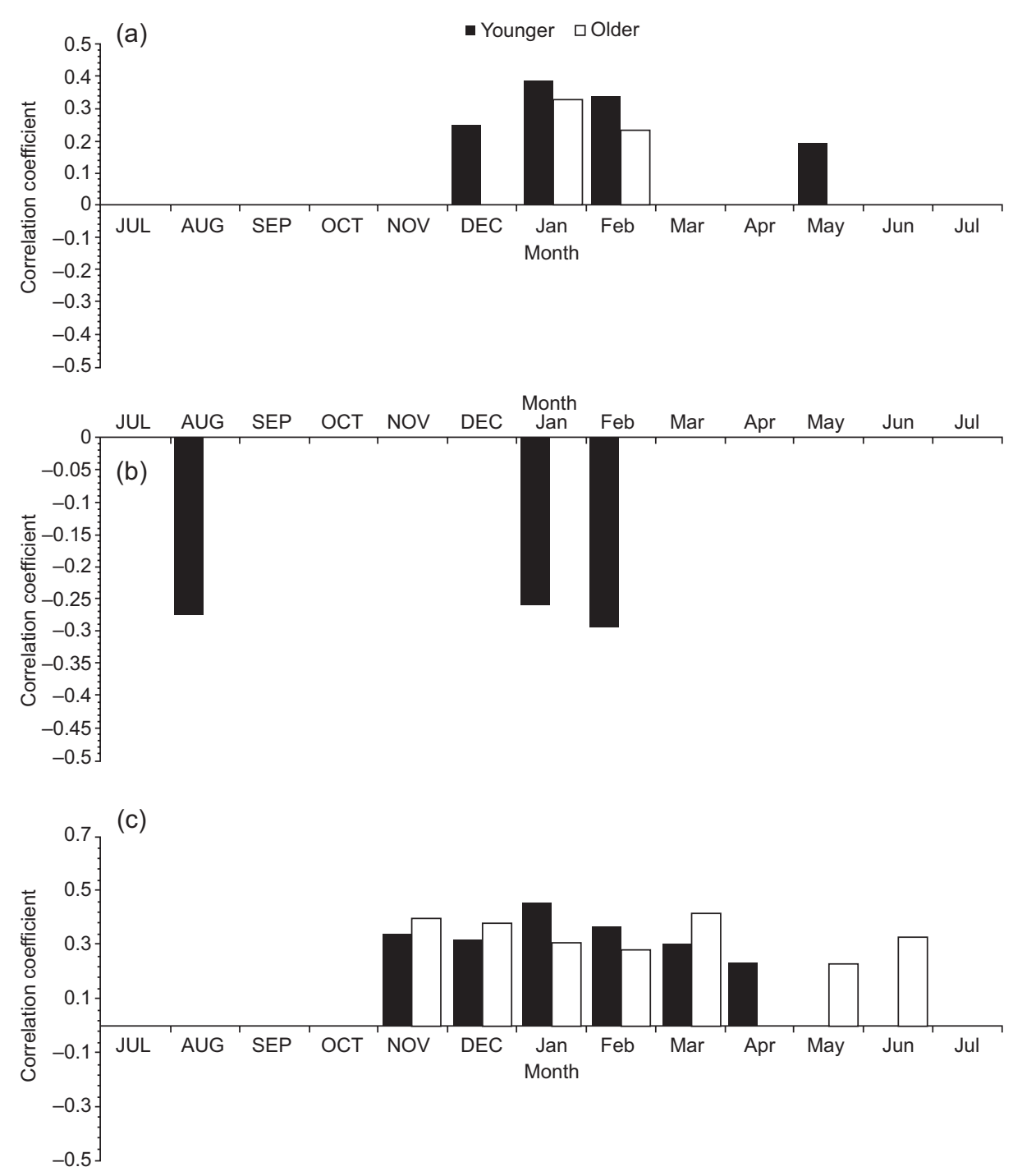

Fig. 3. Correlation coefficients between younger $(<80$ years, black bars) and older $(\geq$ 80 years, white bars) trees with the climatic variables: mean monthly minimum (a) and maximum (b) temperatures; (c) precipitation for the period 1946-2010. Uppercase denotes previous year months (previous to ring formation); lowercase means current year months (regarding the year of tree-ring formation).

Linares et al., 2013; Sun and Liu, 2014). The present study shows that $P$. cooperi trees from the Sierra Madre Occidental in northern Mexico that are younger than 80 years are more sensitive to the influence of climate than older trees. Previous studies have shown that the growth rings of $P$. cooperi respond to climate variability (Pompa-García et al., 2015). However, to the best of our knowledge no related studies have been developed in Mexico and this paper constitutes the first analysis of the effects of age on tree-ring growth in $P$. cooperi.
Our statistical analysis was based on MS, SD, signal-to-noise ratio, EPS and regression procedures (Tables II and III). As shown here, statistics in the age-class chronologies have common features. A slightly higher MS occurs in the younger group, suggesting that younger trees could retain a higher amount of the climate signal. In addition, we found that the growth rate varied by age class. Correlation analysis suggested that warmer $T_{\min }$ enhanced growth (Fig 3a). Warmer $T_{\min }$ in the previous winter may favor radial growth in conifer species owing to 
Table III. Models for age classes selected by stepwise regression for different monthly $T_{\max }$ variables at the 0.10 significance level.

\begin{tabular}{llrrccc}
\hline Age classes & $\begin{array}{c}\text { Monthly } T_{\max } \\
\text { variable }\end{array}$ & $\begin{array}{r}\text { Parameter } \\
\text { estimate }\end{array}$ & $\begin{array}{c}\text { Standard } \\
\text { error }\end{array}$ & $\begin{array}{c}\text { Mean square } \\
\text { error }\end{array}$ & $R^{2}$ & $p$ value \\
\hline \multirow{4}{*}{ Younger } & Intercept & 66.95362 & 19.27709 & & & 0.0010 \\
& January & -0.030470 & 0.00954 & 1.97562 & 0.5 & 0.0022 \\
& November & 0.36952 & 0.11909 & & & 0.0029 \\
& December & 0.25789 & 0.10743 & & 0.0194 \\
\hline \multirow{3}{*}{ Older } & Intercept & 1.01864 & 0.26808 & & 0.0013 \\
& March & -0.02619 & 0.00914 & 0.03464 & 0.13 & 0.0057 \\
& December & 0.02433 & 0.01179 & & & 0.0432 \\
\hline
\end{tabular}

$R^{2}$ : Coefficient determination.

their evergreen foliage, which allows them to take advantage of early growing season warmth when pines typically start photosynthesizing (Huang, et al., 2010). This effect could favor earlier leaf emergence or budburst (Lebourgeois et al., 2012), thus resulting in better growth in the early growing season. Given that tree growth does not respond to precipitation or temperature as independent variables, wet winters with warm nights can lead to enhanced radial growth, whereas hot winter days affect tree growth negatively. Thus, winter rainfall combined with warmer $T_{\min }$ ensures moisture availability and increases carbohydrate reserves for earlywood during the early spring (March), when pines typically start to increase tree-radial growth (Villanueva-Díaz, 1998). If soil moisture is sufficient to maintain foliage water potential and minimize vapor pressure deficits, a proper moisture budget allows optimal tree growth for the next growth season (Dang et al., 1998). In contrast, hot previous winter daytime temperatures $\left(T_{\max }\right)$ could enhance stand respiration and evapotranspiration, thereby resulting in increased water deficits for younger trees (Fig. 3b). This water-stress effect was also confirmed by the linear regression results of Table III. Younger trees had more monthly climate variables related to growth than older trees, showing that the growth in $P$. cooperi varies as the trees age. The different temperature responses of trees imply that the stem contracts during the day, due to transpiration and photosynthesis and expands during the night when water reserves are gradually replenished, which translates in a better overnight hydration (Vieira et al., 2013). Thus, warmer nights encourage growth and warmer days discourage growth by moisture loss.
We found that the effects of rising temperatures during the previous winter are age-dependent for $P$. cooperi, i.e., while warming winter maximum temperatures have negative effects on radial growth that are stronger in younger trees. The climate variables selected by stepwise regression showed that $P W T_{\max }$ is more associated to younger classes than to older ones. This agrees with the findings of $\mathrm{Wu}$ et al. (2013), who showed that younger Picea schrenkiana trees were more sensitive to climate than older trees in the western area of the Tianshan Mountains of north central China. Linderholm and Linderholm (2004) similarly found that younger trees of Pinus sylvestris responded more strongly to unfavorable climatic conditions than the oldest trees. Opała and Mendecki (2014) and Chen et al. (2012) showed that temperature of winter months seems to be one of the most important factors influencing tree-ring formation. Eco-physiological studies have demonstrated that the physiological processes in young and old trees vary; for example, older individuals of various conifer species were shown to have lower photosynthetic rates (Bond, 2000). One explanation for these age related differences is that the less well-established root systems of young trees make them more sensitive to drought (Rozas et al., 2009). Young trees with less efficient root systems are less able to access available water and become water-limited rather easily, while older trees with extensive root systems may tap into deeper water sources, allowing them to have higher rates of transpiration and photosynthesis (Bond, 2000). The climatic sensitivity of trees may also be associated with hydraulic limitations (Carrer and Urbinati, 2004; Yu et al., 2008). Several studies have shown that hydraulic resistance increases with 
size and age in trees with similar environmental conditions. In addition, the rate of photosynthesis generally decreases with tree age; this may occur because old trees have greater access to water, and this occurs because their roots penetrate to greater depths (Bond, 2000).

Some ecologists argue that warming-related drought stress is becoming a major triggering device causing premature forest dieback not only in semiarid but also in temperate ecosystems (Camarero et al., 2011; Candel-Pérez et al., 2012). Furthermore, in a future temporal context, several studies prognosticate that severe drought may occur in the present study region during the coming years (Seager et al., 2009; Pompa-García and Némiga, 2015). This is certainly the case of northern Mexico, where water availability is being continuously reduced by increasing anthropogenic demands and recent drought spells (Seager et al., 2009). In addition, the negative effects on growth observed for the previous August $T_{\max }$ could be related to stomatal control of water loss in the previous year tree-ring formation. McDowell et al. (2008) found that this may reduce carbohydrate synthesis and storage. These finding are in line with Linares et al. (2013). In addition, in Mexico the northern forest populations have become younger following forest management practices (i.e., selectively removing mature trees and preserving younger ones). This could highlight the significance of our results in terms of forest management. We argue that younger forests should be managed by generating mechanisms of adaptation to climate change (Veyreda et al., 2012). As is known, in northern Mexico rising temperatures interact with water availability (Seager et al., 2009). Therefore, recent warming implies reduced growth rate, in particular for younger stands where tree density and competition increases. However, the effect of forest management was outside the scope of this study, implying the need for further research on its impact.

Furthermore, when we compare monthly precipitation with tree-ring chronology, in general we found that radial tree growth in both age classes is similarly limited by precipitation. This inverse relationship can be interpreted as an indirect influence of water deficit on annual increments in younger trees. We suggest that high temperatures impair soil water balance because of increased evapotranspiration. The results show the importance of evapotrans- piration and temperatures as final determinants of the water balance and the functioning of younger trees in drought-prone ecosystems (Williams et al., 2013). Therefore, $T_{\max }$, more than low rainfall, can be a cause of moisture deficiency in younger trees. Although negative correlation between tree growth and summer $T_{\max }$ could be expected, we did not find any such association and further research is needed. We hypothesize that the onset of the NAM in summer negates this potential effect by reducing moisture stress on trees. These results agree with previous studies on other conifers (Sun and Liu, 2015) and were not unexpected because the physiological processes controlling carbon assimilation and growth rate in a tree are expected to change based on its size and age (Rossi et al., 2008; Esper et al., 2008; Wang et al., 2009). During winter the growth of $P$. cooperi shows a positive correlation with precipitation. The increase in photosynthesis during winter may be associated with typical humid winters of the study area (Schaberg, 2000).

\section{Conclusion}

This study analyzes climate-growth relationships of two age classes of $P$. cooperi to help understand the growth patterns of this species. The analysis of $P$. cooperi populations shows that tree-ring growth in younger trees is more sensitive to temperature when compared with that of older trees. Climate change scenarios predict that forests in Mexico will be affected by hydric stress caused by weakening of the Mexican summer monsoon or the delay of its onset date. In this context the increase in temperature would be expected to affect younger trees more than older trees of $P$. cooperi. This may be a major concern if one considers that these forests tend to be younger as a result of recent selective harvesting. Therefore, these results could help land managers develop criteria and management guidelines related to forest management for the Pinus forests of the Sierra Madre Occidental.

\section{Acknowledgments}

We would like to thank the support given by the School of Forestry at Northern Arizona University. The CENID-RASPA Lab from INIFAP supported data gathering and processing. The Universidad Juárez del Estado de Durango, Mexico and CONACYT provided funding through Project 222522. 
The authors are grateful to the editors and two anonymous reviewers for their helpful reviews. Also, we recognize Richard Seager of Lamont Doherty Earth Observatory for his useful comments and suggestions that improved this manuscript.

\section{References}

Biondi F. and K. Waikul, 2004. DendroClim2002: A C++ program for statistical calibration of climate signals in tree-ring chronologies. Comput. Geosci. 30, 303-311, doi:10.1016/j.cageo.2003.11.004.

Blasing T., A. Solomon and D. Duvick, 1984. Response function revisited. Tree-Ring Bull. 44, 1-15.

Bond B. J., 2000. Age-related changes in photosynthesis of woody plants. Trends Plant Sci. 5, 349-353.

Bošel'a M., R. Sedmák, D. Sedmáková, R. Marušák and L. Kulla, 2014. Temporal shifts of climate-growth relationships of Norway spruce as an indicator of health decline in the Beskids, Slovakia. For. Ecol. Manage. 325, 108-117, doi:10.1016/j.foreco.2014.03.055.

Briffa K. R. and T. M. Melvin, 2011. A closer look at regional curve standardization of tree-ring records: Justification of the need, a warning of some pitfalls, and suggested improvements in its application. In: Dendroclimatology: progress and prospects. Developments in paleoenvironmental research (M. Hughes, T. W. Swetnam and H. F. Diaz, Eds.). Springer, the Netherlands, 113-145.

Camarero J. J., C. Bigler, J .C. Linares and E. Gil-Pelegrín, 2011. Synergistic effects of past historical logging and drought on the decline of Pyrenean silver fir forests. For. Ecol. Manage. 262, 759-769, doi:10.1016/j.foreco.2011.05.009.

Candel-Pérez D., J. C. Linares, B. Viñegla and M. E. Lucas-Borja, 2012. Assessing climate-growth relationships under contrasting stands of co-occurring Iberian pines along an altitudinal gradient. For. Ecol. Manage. 274, 48-57, doi:10.1016/j.foreco.2012.02.010.

Carrer M. and C. Urbinati, 2004. Age-dependent tree-ring growth responses to climate in Larix decidua and Pinus cembra. Ecology 85,730-740, doi:10.1890/02-0478.

Chen F., Y. J. Yuan, W. S Wei, S. L. Yu and T. W. Zhang, 2012. Reconstructed temperature for Yong'an, Fujian, Southeast China: Linkages to the Pacific Ocean climate variability. Global Planet. Change 86, 11-19, doi:10.1016/j.gloplacha.2012.01.005.

CNA, 2012. Datos climáticos de estaciones meteorológicas de Durango: El Salto y Otinapa. Comisión Nacional del Agua, México.
Colenutt M. E. and B. H. Luckman, 1991. Dendrochronological investigation of Larix lyallii at Larch Valley, Alberta. Can. J. For. Res. 21,1222-1233, doi:10.1139/ x91-171.

Cook B. I., and R. Seager, 2013. The response of the North American Monsoon to increased greenhouse gas forcing. J. Geophys. Res. Atmos. 118, 1690-1699, doi:10.1002/jgrd.50111.

Cook E., 1985. A time series analysis approach to tree ring standardization. Ph.D. dissertation, University of Arizona, Tucson, $171 \mathrm{pp}$.

Copenheaver C., C. J. Crawford and T. M. Fearer, 2011. Age-specific responses to climate identified in the growth of Quercus alba. Trees 25, 647-653, doi:10.1007/s00468-011-0541-2.

Cruz-Cobos F., H. M. de los Santos-Posadas and J. R. Valdez-Lazalde, 2008. Sistema compatible de ahusamiento-volumen para Pinus cooper Blanco en Durango, México. Agrociencia 42, 473-485.

Dang Q. L., H. A. Margolis, G. J, Collatz, 1998. Parameterization and testing of a coupled photosynthesis-stomatal conductance model for boreal trees. Tree Physiol. 18, 141-153.

Didion M., M. J. Fortin and A. Fall, 2007. Forest age structure as indicator of boreal forest sustainability under alternative management and fire regimes: A landscape level sensitivity analysis. Ecol. Model. 200, 45-58, doi:10.1016/j.ecolmodel.2006.07.011.

Esper J., R. Niederer, P. Bebi and D. Frank, 2008. Climate signal age effects - evidence from young an old trees in the Swiss Engadin. For. Ecol. Manage. 255, 37833789, doi:10.1016/j.foreco.2008.03.015.

Farjon A., 2010. A handbook of the world's conifers. Leiden, the Netherlands, $1112 \mathrm{pp}$.

Fritts H. C., 1976. Tree rings and climate. Academic Press, London, $567 \mathrm{pp}$.

Gadow K.V., S. Sánchez and O. A. Aguirre, 2004. Manejo forestal con bases científicas. Madera y Bosques 10, 3-16.

Hadad M. A., F. Roig Juñent, J. Boninsegna and D. Paton, 2015. Age effects on the climatic signal in Araucaria araucana from xeric sites in Patagonia, Argentina. Plant Ecol. Divers. 8, 343-351, doi:10.1080/175508 74.2014.980350.

Higgins R. W., W. Shi, 2001. Intercomparison of the principal modes of interannual and intraseasonal variability of the North American Monsoon System. J. Climate 14, 403-417, http://dx.doi.org/10.1175/1520-0442(20 01)014<0403:IOTPMO>2.0.CO;2. 
Hinckley T. M., B. Lachenbruch, F. C. Meinzer, and T. E. Dawson, 2011. A lifespan perspective on integrating structure and function in trees. In: Size- and age-related changes in tree structure and function (F. C. Meinzer, B. Lachenbruch and T. E. Dawson, Eds.). Springer, the Netherlands, 3-30.

Hollander M. and D. A. Wolfe, 1973. Nonparametric statistical methods. John Wiley \& Sons, New York, $848 \mathrm{pp}$.

Holmes R., 1983. Computer-assisted quality control in treering dating and measurement. Tree-Ring Bull. 43, 69-75.

Huang J. F., J. C. Tardif, Y. Bergeron, B. Denneier, F. Berninger and M. P. Girardin, 2010. Radial growth response of four dominant boreal tree species to climate along a latitudinal gradient in the Easter Canadian boreal forest. Global Change Biol. 16, 711-731, doi:10.1111/j.1365-2486.2009.01990.x.

Hughes M. K., T. W. Swetnam and H. F. Diaz, 2011. Dendroclimatology: Progress and prospects. Springer, the Netherlands, 227 pp.

Körner C., 2006. Plant $\mathrm{CO}_{2}$ responses: an issue of definition, time and resource supply. New Phytol. 172, 393-411, DOI: 10.1111/j.1469-8137.2006.01886.x.

Lebourgeois F., P. Mérian, F. Courdier, J. Ladier, and P. Dreyfus, 2012. Instability of climate signal in treering width in Mediterranean mountains: A multi-species analysis. Trees-Struct. Funct. 26, 715-729, doi: 10.1007/s00468-011-0638-7.

Linares J. C., L. Taïqui, G. Sangüesa-Barreda, J. I. Seco and J. J. Camarero, 2013. Age-related drought sensitivity of Atlas cedar (Cedrus atlantica) in the Moroccan Middle Atlas forests. Dendrochronologia 31, 88-96, doi:10.1016/j.dendro.2012.08.003.

Linderholm H. W. and K. Linderholm, 2004. Age-dependent climate sensitivity of Pinus sylvestris L. in the central Scandinavian Mountains. Boreal Environ Res. 9, 307-317.

McDowell N., W. T. Pockman, C. D. Allen, D. D. Breshears, N. Cobb, T. Kolb, J. Sperry, A. West, D. Williams and E. A. Yepez, 2008. Mechanisms of plant survival and mortality during drought: why do some plants survive while others succumb to drought? New Phytol. 178, 719-739, doi:10.1111/j.1469-8137.2008.02436.x.

Opała M., and M. J. Mendecki, 2014. An attempt to dendroclimatic reconstruction of winter temperature based on multispecies tree-ring widths and extreme years chronologies (example of Upper Silesia, Southern Poland). Theor. Appl. Climatol. 115, 1-2,73-89, doi:10.1007/s00704-013-0865-5.
Pompa-García M., L. Miranda-Aragón and C. A. Aguirre-Salado, 2015. Tree growth response to ENSO in Durango, Mexico. Int. J. Biometeorol. 59, 89-97, doi:10.1007/s00484-014-0828-2.

Pompa-García M. and A. X. Némiga, 2015. ENSO index teleconnection with seasonal precipitation in a template ecosystem of Northern Mexico. Atmósfera 28, 43-50.

Rossi S., A. Deslauriers, T. Anfodillo and M. Carrer, 2008. Age-dependent xylogenesis in timberline conifers. New Phytol. 177, 199-208, doi:10.1111/j.14698137.2007.02235.x.

Rozas V., L. DeSoto and J. Olano, 2009. Sex-specific, age-dependent sensitivity of tree-ring growth to climate in the dioecious tree Juniperus thurifera. New Phytol. 182, 687-697, doi:10.1111/j.14698137.2009.02770.x.

Ryan M., D. Binkley and J. Fownes, 1997. Age-related decline in forest productivity: Pattern and process. Adv. Ecol. Res. 27, 213-262, doi:10.1016/S00652504(08)60009-4.

SAS, 2004. SAS user's guide statistics. Release 9.1. Statistical Analysis System Institute Inc., Cary, North Carolina, 2170 pp.

Schaberg P. G., 2000. Winter photosynthesis in red spruce (Picea rubens Sarg.): Limitations, potential benefits, and risks. Arct. Antarct. Alp. Res. 32, 375-380.

Schuster R. and W. Oberhuber, 2013. Age-dependent climate-growth relationships and regeneration of Picea abies in a drought-prone mixed-coniferous forest in the Alps. Can. J. For. Res. 43, 609-618, doi:10.1139/cjfr-2012-0426.

Seager R., M. Ting, M. Davis, M. Cane, N. Naik, J. Nakamura, C. Li, E. Cook and Stahle D, 2009. Mexican drought: An observational modeling and tree ring study of variability and climate change. Atmósfera 22, 1-31.

Silva-Flores R., G. Pérez-Verdín and C. Wehenkel, 2014. Patterns of tree species diversity in relation to climatic factors on the Sierra Madre Occidental, Mexico. PloS One 9, 1-16, http://dx.doi.org/10.1371/journal. pone. 0105034 .

Stokes M. and T. Smiley, 1968. An introduction to tree-ring dating. University of Chicago Press, Chicago, 73 pp.

Sun J. and Y. Liu, 2015. Age-independent climate-growth response of Chinese pine (Pinus tabulaeformis Carrière) in North China. Trees 29, 397-406, doi:10.1007/ s00468-014-1119-6.

Stahle D. W. and M. K. Cleaveland, 1993. Southern Oscillation extremes reconstructed from tree rings of the 
Sierra Madre Occidental and southern great plains. $J$. Climate 6, 129-140, http://dx.doi.org/10.1175/1520-0 442(1993)006<0129:SOERFT $>2.0 . C O ; 2$.

Szeicz J. M. and G. M. MacDonald, 1994. Age-dependent tree-ring growth responses of subarctic white spruce to climate. Can. J. For. Res. 24, 120-132.

Veyreda J., J. Martínez-Vilalta, M. Gracia and J. Retana, 2012. Recent climate changes interact with stand structure and management to determine changes in tree carbon stocks in Spanish forests. Glob. Change Biol. 18, 1028-1041, doi:10.1111/j.1365-2486.2011.02606.x.

Vieira J., F. Campelo and C. Nabais, 2009. Age-dependent responses of tree-ring growth and intra-annual density fluctuations of Pinus pinaster to Mediterranean climate. Trees 23, 257-265, doi:10.1007/s00468-008-0273-0.

Vieira J., S. Rossi, F. Campelo, H. Freitas and C. Nabais, 2013. Seasonal and daily cycles of stem radial variation of Pinus pinaster in a drought-prone environment. Agric. For. Meteorol. 180, 173-181, doi:10.1016/j. agrformet.2013.06.009.

Villanueva-Díaz J., 1998. Tree-ring chronologies and ENSO in northern Mexico. In: American Quaternary Association program and abstracts of the 15th Biennial Meeting, Puerto Vallarta, Mexico. AMQUA, 64-65.

Viveros-Viveros H., C. Sáenz-Romero, J. Vargas-Hernández, J. López-Upton, G. Ramírez-Valverde and A. Santacruz-Varela, 2009. Altitudinal variation in Pinus hartwegii Lindl. I: Height growth, shoot phenology and frost damage in seedlings. For. Ecol. Manage. 257, 836-842, doi:10.1016/j.foreco.2008.10.021.
Wang X. Y. Zhang and D. J. MacRae, 2009. Spatial and age-dependent tree-ring growth responses of Larix gmelinii to climate in Northeastern China. Trees 23, 875-885, doi:10.1007/s00468-009-0329-9.

Wigley T., K. Briffa and P. Jones, 1984. On the average value of correlated time series, with applications in dendroclimatology and hydrometeorology. $J$. Clim. Appl. Meteorol. 23, 201-213, http://dx.doi. org/10.1175/1520-0450(1984)023<0201:OTAV$\mathrm{OC}>2.0 . \mathrm{CO} ; 2$.

Williams A. P., C. D. Allen, A. K. Macalady, D. Griffin, C. A. Woodhouse, D. M. Meko, T. W. Swetnam, S. A. Rauscher, R. Seager, H. D. Grissino-Mayer, J. Dean, E. R. Cook, C. Gangodagamage, M. Cai and N. G. McDowell, 2013. Temperature as a potent driver of regional forest drought stress and tree mortality. Nat. Clim. Change 3, 292-297, doi:10.1038/nclimate1693.

Wu G. J., G. B. Xu, T. Chen, X. H. Liu, Y. F. Zhang,W. L. An, W. Z. Wang, Z. A. Fang and S. L. Yu, 2013. Age-dependent tree-ring growth responses of Schrenk spruce (Picea schrenkiana) to climate - a case study in the Tianshan Mountain, China. Dendrochronologia 31, 318-326, doi:10.1016/j.dendro.2013.01.001.

Yu G. R., Y. B. Liu, X. C. Wang and K. P. Ma, 2008. Age-dependent tree-ring growth responses to climate in Qilian juniper (Sabina przewalskii Kom.). Trees 22, 197-204, doi:10.1007/s00468-007-0170-y. 